\title{
How many taxa can be recognized within the complex Tillandsia capillaris (Bromeliaceae, Tillandsioideae)? Analysis of the available classifications using a multivariate approach
}

\author{
Lucía V. Castello', Leonardo Galetto' \\ I Instituto Multidisciplinario de Biologia Vegetal, CONICET, Universidad Nacional de Córdoba \\ Corresponding author: Lucía V. Castello (lvcastello@gmail.com)
}

Academic editor: L. Versieux | Received 15 December 2012 | Accepted 14 May 2013 | Published 20 May 2013

Citation: Castello LV, Galetto L (2013) How many taxa can be recognized within the complex Tillandsia capillaris (Bromeliaceae, Tillandsioideae)? Analysis of the available classifications using a multivariate approach. PhytoKeys 23: 25-39. doi: $10.3897 /$ phytokeys.23.4507

\begin{abstract}
Tillandsia capillaris Ruiz \& Pav., which belongs to the subgenus Diaphoranthema is distributed in Ecuador, Peru, Bolivia, northern and central Argentina, and Chile, and includes forms that are difficult to circumscribe, thus considered to form a complex. The entities of this complex are predominantly small-sized epiphytes, adapted to xeric environments. The most widely used classification defines 5 forms for this complex based on few morphological reproductive traits: T. capillaris Ruiz \& Pav. f. capillaris, T. capillaris f. incana (Mez) L.B. Sm., T. capillaris f. cordobensis (Hieron.) L.B. Sm., T. capillaris f. hieronymi (Mez) L.B. Sm. and T. capillaris f. virescens (Ruiz \& Pav.) L.B. Sm. In this study, 35 floral and vegetative characters were analyzed with a multivariate approach in order to assess and discuss different proposals for classification of the T. capillaris complex, which presents morphotypes that co-occur in central and northern Argentina. To accomplish this, data of quantitative and categorical morphological characters of flowers and leaves were collected from herbarium specimens and field collections and were analyzed with statistical multivariate techniques. The results suggest that the last classification for the complex seems more comprehensive and three taxa were delimited: T. capillaris (=T. capillaris f. incana-hieronymi), T. virescens s. str. (=T. capillaris $\mathrm{f}$. cordobensis) and T. virescens s. l. (=T. capillaris $\mathrm{f}$. virescens). While $T$. capillaris and T. virescens s. str. co-occur, T. virescens s. $l$. is restricted to altitudes above $2000 \mathrm{~m}$ in Argentina. Characters previously used for taxa delimitation showed continuous variation and therefore were not useful. New diagnostic characters are proposed and a key is provided for delimiting these three taxa within the complex.
\end{abstract}

\section{Keywords}

Tillandsia capillaris, Bromeliaceae, species complex, morphometry, distribution

Copyright Lucia V. Castello, Leonardo Galetto. This is an open access article distributed under the terms of the Creative Commons Attribution License 3.0 (CC-BY), which permits unrestricted use, distribution, and reproduction in any medium, provided the original author and source are credited. 


\section{Introduction}

The subfamily Tillandsioideae comprises 10 genera (Smith and Till 1998, Espejo-Serna 2002, Barfuss et al. 2005) of which Tillandsia is the most diversified. In Argentina, Tillandsia is represented by 53 species belonging to the subgenera Anoplophytum (22 spp.), Diaphoranthema (21 spp.), Phytarrhiza (7 spp.), and Allardtia (3 spp.) (Smith and Downs 1977, Luther and Sieff 1994, Zuloaga et al. 2008). Tillandsia capillaris Ruiz \& Pav. belongs to the subgenus Diaphoranthema, which is characterized by small sized species adapted to arid environments, with abundant absorbing trichomes, inflorescences with few inconspicuous flowers with stamens and styles included in the corolla.

Tillandsia capillaris s. $l$. is distributed from southern Ecuador to central Argentina and Chile, between altitudes from $300 \mathrm{~m}$ to $4000 \mathrm{~m}$. (Smith and Downs 1977, Till 1989, Jørgensen and León-Yánez 1999). Plants are epiphytes where the canopy is not a limiting factor (Benzing 1990) and colonize different substrates, from native or exotic trees (Astegiano et al. 2007) to exposed rock, and even power lines, walls and metallic fences. Plants produce chasmogamous and cleistogamous flowers (Gilmartin and Brown 1985) and then fruits with a large number of seeds (Till 1992).

In the dry forests of central Argentina (called Bosque Serrano, Cabido et al. 2010) T. capillaris s. $l$. is abundant and represents most of the biomass of epiphytes on trees (Astegiano et al. 2007). It has been argued that it causes damage to trees when the abundance is high, due to a decrease in the surface of the host shoot buds (Benzing 1990; Caldiz and Fernández 1995; Soria 2007). Current studies attribute medicinal properties to this taxon (Barboza et al. 2006) and it has been also considered as a bioindicator of air quality (Wannaz et al. 2006).

\section{The delimitation of the T. capillaris complex and its taxonomic history}

The T. capillaris complex constitutes a group of related taxa with a gradual morphological variation. The nomenclatural history itself reflects the complex nature of $T$. capillaris and allies. The available classifications (Smith and Downs 1977; Till 1989) do not allow an unequivocal recognition of the entities and suggest the existence of gradients between them. These authors considered these plants difficult to identify; Smith (1935, p. 210) mentioned "this very variable species has a number of forms whose extremes are easily differentiated, but which show all degrees of intergradations in any large collection". Otherwise, Till (1989; p. 33) referring to the complex said "still remains to be clarified by additional studies, if the abundance of the two species have genetic underpinnings, or hybridization processes fade the boundaries between the different forms in both species; names exist in abundance".

In the past two centuries several species that are currently included in the T. capillaris complex were described. Ruiz and Pavon (1802) described T. capillaris Ruiz \& Pav. and T. virescens Ruiz \& Pav. using samples from central Peru. From northern Chile, Gay (1853) described T. propinqua Gay as a related species to T. virescens and 
T. capillaris. Baker (1878) described T. pusilla Gill. ex Baker, T. lanuginosa Gill. ex Baker and T. incana Gill. ex Baker, emphasizing the similarity of the taxa. Hieronymus (1885) made collection trips in central Argentina, describing T. cordobensis Hieron., T. propinqua Gay var. saxicola Hieron., T. lichenoides Hieron. (mistakenly determined by Grisebach in 1874 as $T$. propinqua) and the variety: T. propinqua var. saxicola $\mathrm{Hi}-$ eron. Mez published in 1896 two new species for Argentina: T. hieronymi Mez and T. dependens Hieron. ex Mez, the later with two varieties T. dependens var. perusneoides Mez and T. dependens var. percordobensis Mez; and named new varieties: T. capillaris var. incana Mez, T. capillaris var. lanuginosa Mez. Rusby (1910) described T. williamsii Rusby from Bolivia. Finally, Castellanos (1945a) described also for Argentina the species T. permutata A. Cast. and new varieties and forms: T. hieronymi var. lichenoides (Hieron.) A. Cast., T. virescens var. sanzinii (Hicken) Castell., T. dependens $\mathrm{f}$. perusneoides (Mez) Castell., T. dependens f. percordobensis (Mez) Castell.

The currently accepted classification in Argentina (Zuloaga et al. 2008) is based on the works of Smith $(1935,1969,1970)$ and Smith and Downs (1977), who conducted a review of the genus, defining a single species T. capillaris with 5 forms: T. capillaris Ruiz \& Pav. f. capillaris, T. capillaris f. incana (Mez) L.B. Sm., T. capillaris f. cordobensis (Hieron.) L.B. Sm., T. capillaris f. hieronymi (Mez) L.B. Sm. and T. capillaris $\mathrm{f}$. virescens (Ruiz \& Pav.) L.B. Sm. The separation of these forms is based on only four characters: the number of nerves in the floral bracts, the length of the peduncles, the indument of the floral bracts and the size of the leaves.

The lastest revision of the subgenus Diaphoranthema in South America was done by Till (1989), who accepted two species, $T$. capillaris (reducing to the synonymy $T$. capillaris $\mathrm{f}$. incana, and T. capillaris f. hieronymi) with a distribution area ranging from southern Ecuador to central Argentina, reaching altitudes of $3500 \mathrm{~m}$; and T. virescens (including T. capillaris $\mathrm{f}$. virescens and $T$. capillaris $\mathrm{f}$. cordobensis) with a similar distribution area (the main difference is that it also occurs in Chile), but thriving up to 4300 $\mathrm{m}$. This proposal is also based on a few traits: mainly on differences in the connation of the sepals, the indument of the floral bracts, and the architecture of the sepal veins. Although this classification (Till 1989) can be considered more comprehensive, the classification of Smith and Downs (1977) prevails in the literature.

In this contribution we analyzed the morphological variation of T. capillaris taking as the starting point the five forms defined by Smith and Downs (1977) and cited for Argentina, using 35 floral and vegetative characters with a multivariate approach. These infraspecific taxa are present in many vegetation types in northwestern and central Argentina, where the southern limit of the species is found.

\section{Materials and methods}

Herbarium specimens from CORD and LIL (Holmgren and Holmgren 2001), that were annotated by Lyman B. Smith during his visit to Argentina in 1968 and included in his monograph on Bromeliaceae (Smith and Downs 1977), were used together with 
new additional specimens from field collections, previously identified with Smith and Downs (1977) keys. The herbarium material inquired by Till during his visit to Argentina in 1990 were also included. Supplementary specimens from B, GOET, MA, P, $\mathrm{W}, \mathrm{WU}$ were screened but not incorporated in the analyses. A total of 100 specimens were analyzed (20 of T. capillaris f. capillaris, 26 of T. capillaris f. hieronymi, 19 of T. capillaris $\mathrm{f}$. incana, 12 of T. capillaris $\mathrm{f}$. virescens and 23 of T. capillaris $\mathrm{f}$. cordobensis) from northern and central Argentina, therefore the results are valid for Argentina but not for the whole range of the complex (see supplementary material 1). Each specimen was treated as a taxonomical operational unit (OTU), and 35 floral and vegetative morphological characters were registered, including 12 continuous variables, 7 discontinuous (or discrete) variables, 11 binary variables and 5 multistate variables (Table 1). The morphological features selected include those traits used as key characters in species descriptions by Mez (1896), Castellanos (1945b), Smith and Downs (1977) and Till (1989). All characters were measured in the longest fertile shoot, foliar characters in the most developed leaf, and the character number of leaves per linear $\mathrm{cm}$ of shoot in the middle portion of the shoot.

Table I. Qualitative and quantitative characters used for the morphometric study of the complex Tillandsia capillaris.

\begin{tabular}{|c|c|}
\hline Quantitative characters & Qualitative characters \\
\hline Continuous variables & Binary variables \\
\hline 1-Length of fertile shoot $(\mathrm{mm})$. & 5-Type of stem (simple, ramified: $0 ; 1)$ \\
\hline 2-Length of stem $(\mathrm{mm})$ & 7-Leaf blade apex (rounded, apiculate: $0 ; 1)$ \\
\hline 3-Length of leaf blade (mm). & 8-Arrangement of the leaf (appressed, non appressed: $0 ; 1$ ). \\
\hline 4-(half) Width of leaf blade (mm). & $\begin{array}{l}\text { 10-Leaf sheath exposure (visible, covered by the lower } \\
\text { contiguous sheaths: } 0 ; 1 \text { ). }\end{array}$ \\
\hline 15-Length of scape $(\mathrm{mm})$ & 12-Type of peltate hairs ${ }^{1}$ (type $1+2$, type $\left.1+2+3: 0 ; 1\right)$. \\
\hline 18-(half) Width of bract $(\mathrm{mm})$. & 16-Scape position (axillary, terminal: $0 ; 1)$ \\
\hline 19-Length of floral bract ( $\mathrm{mm})$. & $\begin{array}{l}\text { 20-Floral bract shape (round and wide, triangular and } \\
\text { elongated: } 0 ; 1 \text { ). }\end{array}$ \\
\hline 25-Length of the sepals $(\mathrm{mm})$. & 21-Floral bract apex (acute, mucronate: $0 ; 1)$ \\
\hline 30-Length of fruit $(\mathrm{mm})$ & 26-Sepal dimension (exceeding the bract, equaling the bract: $0 ; 1$ ). \\
\hline 31-(half) Width of fruit $(\mathrm{mm})$. & 29-Sepal shape: (ovate-lanceolate, acute: $0 ; 1$ ) \\
\hline 34-Length of seed $(\mathrm{mm})$ & 32-Endocarp shape (shaped, not shaped: $0 ; 1$ ). \\
\hline \multicolumn{2}{|l|}{ 35-Length of embryo $(\mathrm{mm})$. } \\
\hline Discontinuous (or discrete) variables & Multistate variables \\
\hline 6-Number of branches $\left(\mathrm{n}^{\circ}\right)$ & 9-Type of leaf blade (straight, half-curved, curved: $0 ; 1 ; 2$ ). \\
\hline 11-Number of leaves per linear $\mathrm{cm}$ of shoot $\left(\mathrm{n}^{\mathrm{o}}\right)$. & $\begin{array}{l}\text { 13-Winged trichomes position in the leaf (only in the base, in } \\
\text { the base and in the middle part, in the whole leaf: } 0 ; 1 ; 2 \text { ). }\end{array}$ \\
\hline 17-Number of inflorescences per branch $\left(\mathrm{n}^{\circ}\right)$ & 14-Pilosity of the leaf (low, medium, high: $0 ; 1 ; 2$ ). \\
\hline 22-Number of nerves in the floral bract $\left(\mathrm{n}^{\circ}\right)$. & $\begin{array}{l}\text { 24-Floral bract indument (glabrous, half pubescent, pubescent: } \\
0 ; 1 ; 2) \text {. }\end{array}$ \\
\hline $\begin{array}{l}\text { 23-Number of nerves joined together at the } \\
\text { apex of bracts }\left(\mathrm{n}^{\circ}\right) \text {. }\end{array}$ & 33-Exocarp shape (straight, curved, very curved: $0 ; 1 ; 2$ ). \\
\hline \multicolumn{2}{|l|}{ 27-Association degree of the adaxial sepals (\%). } \\
\hline 28-Association degree of the abaxial sepals (\%). & \\
\hline
\end{tabular}

${ }^{1}$ Types of trichomes: 1-radially symmetric, 2-one developed wing, 3-two wings developed 


\section{Statistical analyses}

Non-parametric Kruskal-Wallis tests $(\mathrm{KW})$ were run for all the variables among the taxa considered. Box-plots were made for continuous variables.

A two-steps analysis was carried out to detect the most informative characters. First, a Principal Component Analysis (PCA) was run using all characters (Woods et al. 2005, Denham et al. 2006, Blanco-Dios 2007, Nicolalde-Morejón 2005), obtaining a correlation matrix with the Pearson coefficient (Sokal and Rohlf 1995), and selecting afterwards characters with coefficient $>0.20$ as input for a second analysis. With the new matrix (which contained less variables), a Principal Coordinates Analysis (PCoA) was run, using the Gower coefficient (Gower 1971; Hernández 1997; Correa et al. 2007). Dispersion graphs were done for PCA and PCoA with INFOSTAT software (Di Rienzo et al. 2009).

\section{Results}

Results of character comparisons showed significant differences (Fig. 1; except for "number of branches" - KW test; $H=4.68 ; P=0.24$ ) among the putative taxa but with unclear trends (Fig. 1). For example, T. capillaris f. virescens showed significantly lower values compared to the other taxa for several traits (length of: fertile shoot, leaf blade, scape, fruit, seed and of embryo; Figs $1 \mathrm{a}, \mathrm{c}, \mathrm{d}, \mathrm{g}, \mathrm{h}, \mathrm{i}$ respectively). T. capillaris f. cordobensis differed from all the other forms by the longer size of leaves, of floral bracts, of sepals, the lower number of leaves per linear $\mathrm{cm}$ of shoot and the highest number of nerves joined together at the apex of bracts (Figs 1c, e, f, j, k, respectively). T. capillaris $\mathrm{f}$. hieronymi showed significant differences with an intermediate size of the fertile shoot, the scapes, and lower number of nerves joined together at the apex of bracts (Figs $1 \mathrm{a}, \mathrm{d}, \mathrm{k}$ ). T. capillaris $\mathrm{f}$. capillaris and T. capillaris $\mathrm{f}$. incana did not show significant differences and these forms are overlapped with the other forms considering this set of characters (Figs 1a-l).

In the PCA, the first three components explained $50.5 \%$ of variability $(25.9,16.5$, and $8.1 \%$ respectively) (results not shown). Analyzing the variables individually, only 19 variables were selected to explain the variance among taxa (see material and methods), considering the ones which showed values up to 0.20 (Table 2). A second PCA using these 19 characters showed that the principal two axes provide a clear ordination of the OTUs into separate groups (Figure 2). The two principal axes together account for $64.4 \%$ of the variability. The variance of the first component included quantitative variables (lengths of leaf blade, bract, and sepals, number of leaves per linear cm of shoot, and fusion degree of the adaxial sepals), and qualitative variables (arrangement of the leaf, sepal dimension, type of leaf blade, floral bract shape, sepal shape, indument of the floral bract and leaf sheath exposure). The variance of the second component was supported by quantitative variables concerning the vegetative and the inflorescence size (lengths of fertile shoot, stem, scape, fruit, seed, embryo, and width 

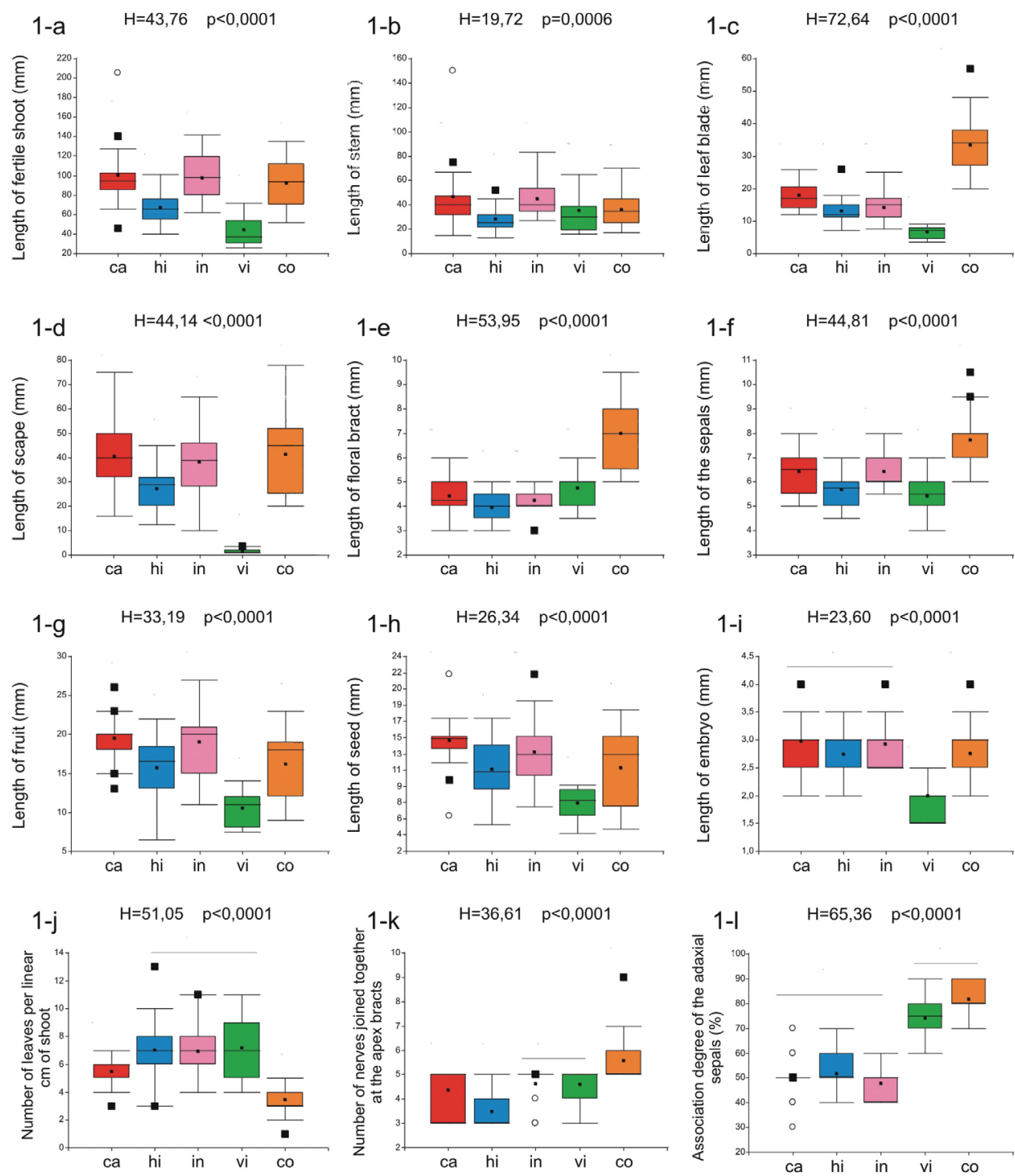

Figure I. Quantitative analyses of reproductive and vegetative traits in the complex Tillandsia capillaris in Argentina. Box plots featuring medians (solid black square), means, and first and third quartiles (large box). Kruskal-Wallis $(\mathrm{H})$ tests performed of selected characters are also included. Different letters above box-plots indicate statistical differences among taxa using a posteriori Dunn tests $(\mathrm{p}=0,05)$ (Balzarini et al. 2008). References: OTUs: ca: capillaris $(\mathrm{n}=21)$; hi: hieronymi $(\mathrm{n}=24)$; in: incana $(\mathrm{n}=20)$; vi: virescens $(\mathrm{n}=12)$; co: cordobensis $(\mathrm{n}=23)$.

of bract; Table 2). Figure 2 shows the grouping tendency among the OTUs for this set of 19 variables.

PCoA showed that the two principal axes provide a clear ordination of the OTUs into three separate groups (Fig. 3). The two principal axes together account for $54.6 \%$ 
Table 2. Title: Principal components analysis results for the Tillandsia capillaris complex. Legend: PCA results for 5 taxa of the complex T. capillaris using 35 quantitative and qualitative traits (see M\&M for details). The percentages of variance for the two principal components were obtained in the PCA analysis from all the characters. ${ }^{*}$ indicates the values $>0.20$

\begin{tabular}{l|l|l}
\hline & \multicolumn{2}{l}{ Principal components } \\
\hline Character & Axis 1 & Axis 2 \\
\hline Length of fertile shoot (LgFS) & 0.06 & $0.36^{*}$ \\
\hline Length of stem (LgSt) & $3.8 \mathrm{E}-03$ & $0.22^{*}$ \\
\hline Length of leaf blade (LgLB) & $0.25^{*}$ & 0.12 \\
\hline Width of leaf blade (WdLB) & -0.08 & 0.19 \\
\hline Length of scape (LgSc) & 0.08 & $0.33^{*}$ \\
\hline Width of floral bract (WdFB) & 0.14 & $0.23^{*}$ \\
\hline Length of floral bract (LgFB) & $0.29^{*}$ & 0.08 \\
\hline Length of the sepals (LgSp) & $0.22^{*}$ & $0.24^{*}$ \\
\hline Length of fruit (LgFr) & -0.03 & $0.34^{*}$ \\
\hline Width of fruit (WdFr) & 0.12 & 0.19 \\
\hline Length of seed (LgSd) & -0.03 & $0.29^{*}$ \\
\hline Length of embryo (LgEm) & -0.01 & $0.25^{*}$ \\
\hline Number of branches (NBr) & -0.03 & 0.09 \\
\hline Number of leaves per linear cm of shoot (NLS) & $-0.22^{*}$ & -0.08 \\
\hline Number of inflorescences per branch (NIB) & -0.04 & 0.09 \\
\hline Number of nerves in the floral bract (NNB) & 0.15 & 0.17 \\
\hline Number of nerves joined together at the apex of bracts (NNA) & 0.20 & 0.11 \\
\hline Fusion degree of the adaxial sepals (FDAd) & $0.27^{*}$ & -0.14 \\
\hline Fusion degree of the abaxial sepals (FDAb) & -0.11 & 0.14 \\
\hline Type of stem (TySt) & -0.04 & 0.08 \\
\hline Leaf blade apex (LBAp) & -0.13 & -0.02 \\
\hline Arrangement of the leaf (ArLf) & $0.26^{*}$ & -0.05 \\
\hline Type of leaf blade (TyLB) & $0.22^{*}$ & $-4.9 \mathrm{E}-03$ \\
\hline Leaf sheath exposure (LSEx) & $-0.27^{*}$ & 0.10 \\
\hline Type of peltate hairs (TyPH) & 0.01 & 0.09 \\
\hline Winged hairs position in the leaf (WHPL) & -0.16 & 0.20 \\
\hline Pilosity of the leaf (PiLf) & -0.16 & 0.05 \\
\hline Scape position (ScP) & 0.06 & -0.13 \\
\hline Floral bract shape (FBSh) & $0.26^{*}$ & 0.04 \\
\hline Floral bract apex (FBA) & 0.05 & -0.05 \\
\hline Floral bract indument (FBPb) & $0.29^{*}$ & -0.14 \\
\hline Sepal dimension (SpSz) & $0.25^{*}$ & -0.03 \\
\hline Sepal shape (SpSh) & $0.27^{*}$ & -0.16 \\
\hline Endocarp shape (EnSh) & 0.05 & -0.09 \\
\hline Exocarp shape (ExSh) & & \\
\hline & & \\
\hline
\end{tabular}

of the variability using the 19 characters previously selected in the PCA with coefficient $>0.20$ (Fig. 3). There is a clear distinction with a larger left-group formed by the T. capillaris $\mathrm{f}$. capillaris, T. capillaris $\mathrm{f}$. hieronymi and T. capillaris $\mathrm{f}$. incana OTUs; a second central, upper-group formed by the T. capillaris f. virescens OTUs; and a third lower, right-group corresponding to the OTUs for T. capillaris f. cordobensis. 


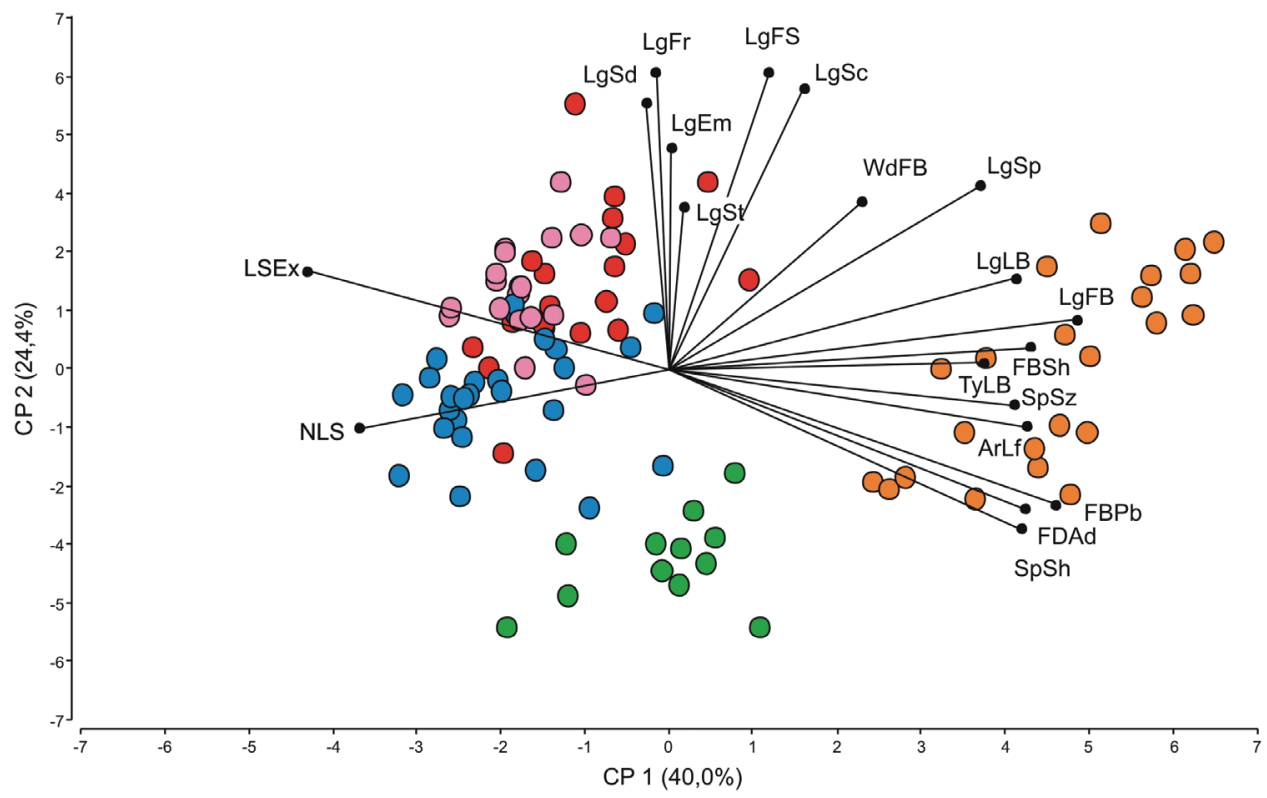

Figure 2. PCA for 5 different taxa of the Tillandsia capillaris complex. Plot of all specimens (100 OTUs) and leaning of the most influential 19 characters represented on the first two principal components resulting from principal component analysis (see Table 2 for abbreviations). References: OTUs: f. capillaris $(\mathrm{n}=21)=\mathrm{red}$; . hieronymi $(\mathrm{n}=24)=$ blue; f. incana $(\mathrm{n}=20)=$ pink; f. virescens $(\mathrm{n}=12)=$ green; f. cordobensis $(\mathrm{n}=23)=$ orange.

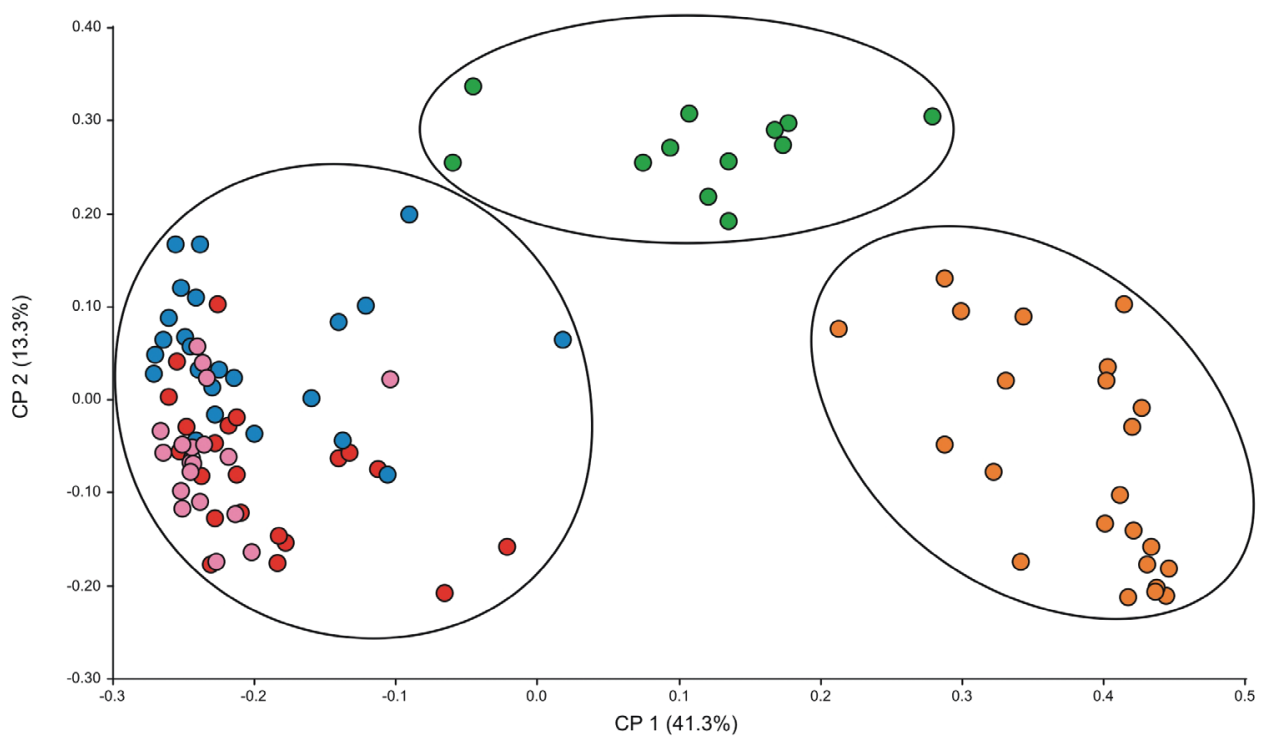

Figure 3. Principal coordinates analysis (PCoA) for 5 different taxa of the Tillandsia capillaris complex. Scatterplots of the first two axis based on 19 characters selected in the PCA and using the Gower distance (sqrt(1-S)). References: Characters used (see Table I); OTUs: f. capillaris $(\mathrm{n}=21)=\mathrm{red}$; f. hieronymi $(\mathrm{n}=24)=$ blue; f. incana $(\mathrm{n}=20)=$ pink; f. virescens $(\mathrm{n}=12)=$ green; f. cordobensis $(\mathrm{n}=23)=$ orange. 

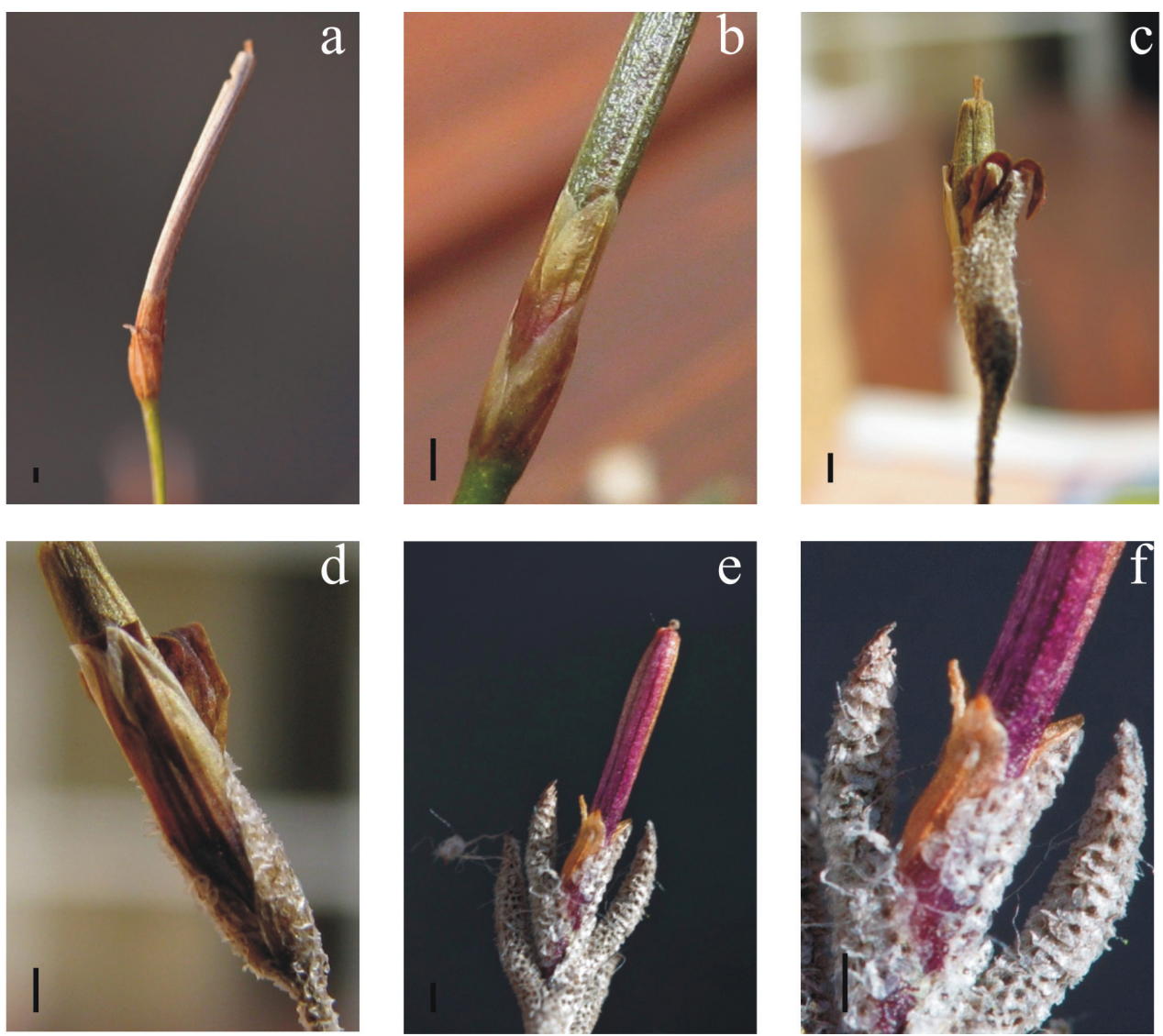

Figure 4. Infructescence structure in Tillandsia capillaris complex. a-b T. capillaris (=T. capillaris $\mathrm{f}$. incana and $T$. capillaris $\mathrm{f}$. hieronymi) a glabrous floral bracts much shorter than the sepals $\mathbf{b}$ the ovatelanceolate sepals are partially fused $\mathbf{c}-\mathbf{d} T$. virescens $\mathrm{s}$.str. $(=$ T. capillaris $\mathrm{f}$. cordobensis $)$ c pubescent floral bracts equaling the sepals $\mathbf{d}$ the acute sepals are much more fused (60-90\%) e-f T virescens s. $l$. $(=T$. capillaris f. virescens) e pubescent floral bracts equaling the sepals, lacking scapes and violet capsules $\mathbf{f}$ the acute sepals are almost totally fused. Abbreviations: $s=$ sepals; $b=$ floral bract, bars $=1 \mathrm{~mm}$.

Many of the 19 most influential characters are useful to separate $T$. capillaris $\mathrm{f}$. incana-hieronymi (=T. capillaris sensu Till) (Fig. 4a, b), T. capillaris $\mathrm{f}$. cordobensis $(=T$. virescens s. str. sensu Till) (Fig. $4 \mathrm{c}, \mathrm{d}$ ) and $T$. capillaris $\mathrm{f}$. virescens $(=T$. virescens $s$. $l$. sensu Till) (Fig. 4e, f). For example, characters such as: triangular and elongated floral bract; sepals long, acute and equaling the bract; elongated and curved leaf blades; and low number of leaves per linear $\mathrm{cm}$ of shoot are useful to delimit T. capillaris $\mathrm{f}$. cordobensis. The second group formed by T. capillaris f. capillaris, T. capillaris f. incana and T. capillaris $\mathrm{f}$. hieronymi can be circumscribed by: ovate-lanceolate sepals, exceeding in length the floral bract; round and wide floral bract; and straight and half-curved leaf blade. Finally, T. capillaris f. virescens (=T. virescens s. l.) has the smaller sizes of the fertile shoot, scape, leaf blade, fruit, seed, and embryo. This last form showed 
statistically similarities in some of the characters (length of the fertile shoot, scape and sepals; Figs $1 \mathrm{a}, \mathrm{d}$, f, respectively) with $T$. capillaris $\mathrm{f}$. hieronymi. Nevertheless, the characters indument of the bract, shape of the sepals and fusion degree of the adaxial sepals allowed to separate the forms in two different groups (Fig. 2).

Key for the recognition of the morphotypes proposed for the T. capillaris complex in Argentina

$1 \quad$ Floral bracts glabrous. Sepals ovate-lanceolate, partially fused, exceeding in length the floral bracts ....T. capillaris (=T. capillaris f. incana-bieronymi)

- $\quad$ Floral bracts pubescent or semi-pubescent. Sepals acute, almost totally fused, equaling or barely exceeding in length the floral bracts.

2 Scapes developed (2-8 cm in length). Leaf blades elongated and curved, 2-6 $\mathrm{cm}$ long. Low number of leaves per linear $\mathrm{cm}$ of shoot $(<4-5$ leaves). Leaf sheaths widely visible. Sepals acute connated by $60-90 \%$ of their lengths, with 5-9 nerves. Floral bracts triangular and elongate

T. virescens s. str. (=T. capillaris f. cordobensis)

- $\quad$ Scape absent or scarcely developed (1-3.5 mm in length). Leaf blades straight and half-curved, shorter than $1 \mathrm{~cm}$. Leaves per linear $\mathrm{cm}$ of shoot 5-11. Leaf sheaths barely visible. Sepals acute almost totally fused and with 1-3 nerves. Floral bracts round and wide ... T. virescens s. $l$. (=T. capillaris f. virescens)

\section{Discussion}

The criteria used in previous classifications (Smith and Downs 1977, Till 1989) are not satisfying to resolve the complexity of this group. Nevertheless, when the number of qualitative and quantitative characters is increased, a pattern emerged through a multivariate test allowing the separation of the putative taxa into three recognizable groups. The application of morphometric studies in the Bromeliaceae currently prevails in the literature to resolve different complex groups (Wendt et al. 2000, Costa et al. 2009, Pinzón et al. 2011) stressing the potential of this statistical tool to evaluate the limits between closely related taxa (Sokal and Rohlf 1995).

Among the characters analyzed, most were informative (approximately 63\% of the quantitative and $44 \%$ of the qualitative characters). The quantitative characters are significant to separate groups, while the categorical characters were useful when the taxa had similar plant size (e.g. T. capillaris $\mathrm{f}$. virescens and T. capillaris $\mathrm{f}$. hieronymi). Within the non-informative qualitative characters, those referred to the peltate trichomes ( $\mathrm{TyPH}$, WHPL and PiLf) were cited in previous classifications (Hieronymus 1885). We suggest to avoid the use of these characters for taxonomic purposes, unless a detailed morphometric study is done. Once, environmental variation for the number of trichomes and the size of the wing area in Tillandsia has been suggested (Stefano et al. 2008). 
Diagnostic characters used by Smith and Downs (1977) were useless to differentiate the forms T. capillaris f. capillaris, T. capillaris $\mathrm{f}$. hieronymi and T. capillaris $\mathrm{f}$. incana ocurring in Argentina, because these taxa showed a gradual variation in many characters (e.g., the number of nerves in the floral bract, the length and position of the scape, the length and diameter of the leaves). For example, T. capillaris $\mathrm{f}$. incana described by Smith and Downs (1977) with short, wide and appressed leaf blades did not show statistically significant differences in any of these characters when it was compared with the other forms. Tillandsia capillaris $\mathrm{f}$. hieronymi was previously circumscribed by the 3 nerves joined together at the apex of the floral bract (Smith and Downs 1977). Nevertheless, this was a variable character, varying from 3-5 nerves in the three forms of the "capillaris" complex defined here. Also, T. capillaris f. capillaris did not show statistical differences in the scape position (Smith and Downs 1977). This variable seems to be related with the development of the stem (Castellanos 1945b), and it was registered for all the forms terminal and axillary inflorescences.

On the contrary, other diagnostic characters established by Smith and Downs (1977) to determine T. capillaris f. cordobensis and T. capillaris f. virescens showed statistically significant differences. Tillandsia capillaris $\mathrm{f}$. cordobensis can be circumscribed by both the indument of the floral bracts (Fig. 4c, d) and wide spreading leaves (the leaf sheaths are prominent and visible so that the leaf blades are detached). In addition, some complementary characters allow an easier delimitation of this taxon, as the exposure of the leaf sheaths or the leaf density per $\mathrm{cm}$ of stem. Tillandsia capillaris $\mathrm{f}$. virescens can be recognized by the lacking of a scape (Smith and Downs 1977) (Fig. 4e, f). It is interesting to note that the reduction of the reproductive organs in this taxon could be a feature related to environment constraints (altitude) where this form lives (Gilmartin and Brown 1985).

Till (1989) used the fusion degree of the adaxial and abaxial sepals as the main character to delimit the complex into two groups: one with adaxial sepals partially fused (20-60\%) (Fig 4b) and abaxial sepals fused by their bases (10-35\%) (T. capillaris=T. capillaris f. incana-hieronymi); a second group with adaxial sepals more fused (50-90\%) (Fig. 4d, f), and abaxial sepals less fused (5-20\%) (T. virescens s. str. and s. l. $=$ T. capillaris $\mathrm{f}$. cordobensis and T. capillaris f. virescens). Data for the material studied here showed values of $40-70 \%$ fusion for the adaxial sepals in the first group (T. capillaris=T. capillaris $\mathrm{f}$. incana-hieronymi), and $60-90 \%$ in the second group (T. virescenss. str. and s. l.=T. capillarisf. cordobensis and T. capillaris f. virescens). Although the trend described by Till (1989) for the abaxial sepals was detected, statistical differences supported the separation of the complex into three groups. Till (1984) considered T. virescens as one species, and T. cordobensis as a taxonomic synonym of T. virescens (Till 1984, p. 135-136), and defined five aggregates for " $T$. virescens". After revising the herbarium material that he studied, we interpreted that $T$. virescens s. str. (=T. capillaris f. cordobensis) comprise "group 1: $T$. cordobensis" and "group 2: T. cordobensis "var." tucumanensis nom. nud.". Otherwise, T. virescens s. l. (=T. capillaris f. virescens) include "group 4: T. propinqua "var."” (Till 1984). Till (1989) also used the architecture of the veins of the sepals as a character, but we did not consider it here because to exam such feature we would cause severe damage to her- 
barium specimens. Other characters briefly mentioned by Till (1989; shape of the bract and size of the sepals) were measured here and were significant to separate the taxa.

Summarizing, our results partially support the classification of Till (1989) that considered the first group as T. capillaris since the OTUs for T. capillaris f. capillaris, T. capillaris f. hieronymi and T. capillaris $\mathrm{f}$. incana tend to form a single ensemble. On the other hand, concerning the differences between T. capillaris f. cordobensis and $T$. capillaris f. virescens, the classification by Smith and Downs (1977) is still appropiatted. However, we are also evaluating the taxonomical thesis of Till (1984) and considered his classification ("T. virescens and aggregates") in future taxonomical work for the complex, since we saw that the characters he used (the cohesion of the sepals and the indument of the floral bract) were useful to defined these groups. We expect to propose conclusive nomenclatural changes, however, only after gathering additional data. Taxonomic resolution of complex groups, ideally, should be done combining morphological data from the whole range of distribution.

\section{The T. capillaris complex in Central Argentina}

All the forms analyzed are distributed in the central and northern Argentina, in the southern distributional range of the complex. The taxa T. capillaris (=f. incana- hieronymi) and T. virescens s. str. (=f. cordobensis), co-occur in almost the same sites and altitude levels. Tillandsia virescens s. str. was mentioned by Smith and Downs (1977) for altitudes above $900 \mathrm{~m}$. We found populations at lower altitudes $(300 \mathrm{~m})$, co-occurring with $T$. capillaris. On the other hand, T. virescens s. $l$. (=f. virescens), with saxicolous habit, was found restricted to higher altitudes in the central Argentina (above $2000 \mathrm{~m}$; Achala batholith), or in the western foothill of the Andes (between 2000-3500 m). It is interesting to note that in some regions and at higher altitudes $(2000 \mathrm{~m}$, for example in the central Argentina), the three forms can co-occur, but at lower altitudes (as in the woodland mountains of Bosque Serrano at, 400-1100 m) only two of these forms can be found (T. capillaris and T. virescens s. str.).

\section{Conclusion}

The main goal of this contribution was to analyze the available classifications of the T. capillaris complex using a relatively large sample of material with a multivariate perspective. This methodological approach allowed us to define three taxa in Argentina (Figs 3 and 4) with clear morphological limits, and to inquire into the conflicts between the available classifications. The next step is to compare these results using new material from other populations within the geographical range of the complex, specifically from Bolivia and Peru. We are not proposing new nomenclature combinations until the whole distribution area are investigated. 


\section{Acknowledgements}

We thank Jorge Chiapella, Walter Till, and Sabina Donadío for useful taxonomic discussions on the complex. Also to Leonardo Versieux, Andrea Costa, Walter Till and Jorge Chiapella for helpful comments and suggestions of previous version of this manuscript. We are indebted to the curators of CORD, LIL, MA, W, and WU for access to plant material. We thank also to Marcelo Gritti that took some of the photographs. Financial support was provided by CONICET, SECyT (UNC), MINCyT and BMFW.

\section{References}

Astegiano J, Ferreras A, Torres C, Subils R, Galetto L (2007) Proliferación de "claveles del aire" (I): diversidad sobre algarrobos de jardines domésticos y percepción de los pobladores. Kurtziana 33: 203-215.

Baker JG (1878) A synopsis of the species of Diaphoranthema. Journal of Botany, British and Foreign 16: 236-241.

Barboza GE, Cantero JJ, Nuńez C, Ariza Espinar L (2006) Flora medicinal de la provincia de Córdoba (Argentina): pteridófitas y antófitas silvestres o naturalizadas. Museo Botánico, Córdoba, Argentina.

Balzarini M, Gonzalez L, Tablada M, Casanoves F, Di Rienzo JA, Robledo CW (2008) Infostat. Manual del Usuario. Editorial Brujas, Córdoba, Argentina.

Barfuss MHJ, Samuel R, Till W, Stuessy TF (2005) Phylogenetic relationships in subfamily Tillandsioideae (Bromeliaceae) based on DNA sequence data from seven plastid regions. American Journal of Botany 92: 337-351.

Benzing DH (1990) Vascular epiphytes: General biology and related biota. University Press, Cambridge. doi: $10.1017 / \mathrm{CBO} 9780511525438$

Blanco-Dios JB (2007) Estudio morfométrico de una zona híbrida entre Armeria beirana y A. pubigera (Plumbaginaceae) en el noroeste de la Península Ibérica. Anales del Jardín Botánico de Madrid 64(2): 229-235. doi: 10.3989/ajbm.2007.v64.i2.180

Cabido M, Giorgis M, Tourn M (2010) Guía para una excursión botánica en las sierras de Córdoba. Boletín de la Sociedad Argentina de Botánica 45(1-2): 209-219.

Caldiz DO, Fernández LV (1995) The role of the epiphytic weeds Tillandsia recurvata and T. aëranthos in native rural and urban forest. International Journal of Ecology and Environmental Sciences 21: 177-197.

Castellanos A (1945a) Bromeliaceae Argentinae Novae vel criticae VI. Lilloa 11: 135-151.

Castellanos A (1945b) Bromeliaceae. In: Descole HR (Ed) Genera et species plantarum Argentinarum 3, Guillermo Kraft Ltda, Buenos Aires, 107-353.

Correa G, Lavalett L, Galindo MP, Afanador L (2007) Uso de métodos multivariantes para la agrupación de aislamientos de Colletotrichum spp. con base en características morfológicas y culturales. Revista Facultad Nacional de Agronomía, Medellín 60(1): 3671-3690. 
Costa AF, Rodrigues PJFP, Wanderley MDGL (2009) Morphometric analysis and taxonomic revision of the Vriesea paraibica complex (Bromeliaceae). Botanical Journal of the Linnean Society 159:163-181. doi: 10.1111/j.1095-8339.2008.00919.x

Denham S, Múlgura de Romero ME, Slanis A, Bulacio E (2006) Lippia integrifolia versus L. boliviana (Verbenaceae). Darwiniana 44(2): 363-374.

Di Rienzo JA, Casanoves F, Balzarini MG, Gonzalez L, Tablada M, Robledo CW (2009) Infostat, versión 2009. Grupo Infostat, FCA, Universidad Nacional de Córdoba.

Espejo-Serna A (2002) Viridantha, un ge'nero nuevo de Bromeliaceae (Tillandsioideae) endémico de México. Acta Botánica Mexicana 60: 25-35.

Gay C (1853) Historia Física y Política de Chile, Botánica 6. Museo de Historia Natural de Santiago, Chile.

Gilmartin AJ, Brown GK (1985) Cleistogamy in Tillandsia capillaris (Bromeliaceae). Biotropica 17: 256-259. doi: 10.2307/2388227

Gower JC (1971) A general coefficient of similarity and some of its properties. Biometrics 27: 857-871. doi: 10.2307/2528823

Grisebach A (1874) Plantae Lorentzianae, Bearbeitung der ersten und zweiten Sammlung argentinischer Pflanzen des Professor Lorentz zu Cordoba. Dieterichsche Buchhandlung, Göttingen.

Hernández JM (1997) Variabilidad fenotípica inter e intraespecífica en cuatro especies de Iberodorcadion Breuning, 1943 (Coleoptera, Cerambycidae, Lamiinae) de la Sierra de Guadarrama (Madrid, España). Miscellánia Zoológica 20: 93-100.

Hieronymus G (1885) Icones et descriptiones plantarum, quae sponte in Republica Argentina crescunt, Lieferung 1. Druck der breslader genossenschafts-buchdruckerei, eingetr, Genossenschaft, Wroclaw.

Holmgren PK, Holmgren NH (2001) Index Herbariorum on the Internet [information for 3167 herbaria and 9534 associated staff members in 165 countries].

Jørgensen PM, León-Yánez S (1999) Catálogo de plantas vasculares del Ecuador. Missouri Botanical Garden, Saint Louis.

Luther HE, Sieff E (1994) De Rebus Bromeliacearum I. Selbyana 15:9-93.

Mez C (1896) Bromeliaceae. In: De Candolle ALPP, De Candolle ACP (Ed) Monographiae Phanerogamarum 9: 658-881. Sumptibus Masson \& $C^{\text {ie., }}$ Paris.

Nicolalde-Morejón F (2005) Circunscripción de la especie del complejo Zamia katzeriana (Zamiaceae-Cycadales). MA Thesis, Instituto de ecología A.C., México.

Pinzón JP, Ramírez-Morillo IM, Fernández-Concha GC (2011) Morphometric analyses within the Tillandsia utriculata L. complex (Bromeliaceae) allow for the recognition of a new species, with notes on its phylogenetic position. Journal of the Torrey Botanical Society 138(4): 353-365. doi: 10.3159/TORREY-D-11-00005.1

Ruiz H, Pavon JA (1802) Flora Peruviana. Descriptiones et Icones Plantarum Peruvianarum, et Chilensium 3: 1-95. Gabrielis de Sancha, Madrid.

Rusby HH (1910) New species from Bolivia, collected by RS Williams. Bulletin of the New York Botanical Garden 6: 489.

Smith LB (1935) Studies in the Bromeliaceae -VI. Proceedings of the American Academy of Arts and Sciences 70: 209-214. doi: 10.2307/20023130 
Smith LB (1969) The Bromeliaceae of Bolivia. Rhodora 71: 220-279

Smith LB (1970) Notes on Bromeliaceae XXXI. Phytologia 20: 121-183.

Smith LB, Downs RJ (1977) Tillandsoideae (Bromeliaceae). Flora Neotropica. Monograph 14(2). Hafner Press, New York.

Smith LB, Till W (1998) Bromeliaceae. In: Kubitzki K (Ed) The families and genera of vascular plants. Springer, Berlin. 4: 74-99.

Sokal RR, Rohlf JF (1995) Biometry, the principles of practice of statistic in biological research, $3^{\text {rd }}$. edition. W. H. Freeman, New York.

Soria N (2007) Efectos del asentamiento de "claveles del aire" sobre la foliación de Prosopis alba. Undergraduate Thesis, FCEFyN, Universidad Nacional de Córdoba, Argentina.

Stefano M, Papini A, Brighigna L (2008) A new quantitative classification of ecological types in the bromeliad genus Tillandsia (Bromeliaceae) based on trichomes. Revista de Biología Tropical 56(1): 191-203.

Till W (1984) Sippendifferenzierung innerhalb Tillandsia subgenus Diaphoranthema in Südamerika mit besonderer Berücksichtigung des Andenostrandes und der angrenzenden Gebiete. PhD Thesis, Universität Wien, Austria.

Till W (1989) Die Untergattung Diaphoranthema (Beer) C. Koch von Tillandsia Linnaeus. Bromelie 1989/2: 31-34.

Till W (1992) Systematics and evolution of the subtropical Tillandsia subgenus Diaphoranthema (Bromeliaceae). Selbyana 13: 88-94.

Wannaz ED, Carreras HA, Pérez CA, Pignata ML (2006) Assessment of heavy metal accumulation in two species of Tillandsia in relation to atmospheric emission sources in Argentina. Science of the Total Environment 361: 267-278. doi: 10.1016/j.scitotenv.2005.11.005

Wendt T, Ferreira Canela MB, Morrey-Jones JE, Henriques AB, Iglesias Rios R (2000). Recognition of Pitcairnia corcovadensis (Bromeliaceae) at the species level. Systematic Botany 25(3): 389-398. doi: 10.2307/2666685

Woods K, Hilu KW, Wiersema JH, Borsch T (2005) Pattern of variation and systematics of Nymphaea odorata: I. Evidence from morphology and Inter-Simple Sequence Repeats (ISSRs). Systematic Botany 30(3): 471-480. doi: 10.1600/0363644054782161

Zuloaga FO, Morrone O, Belgrano MJ (Eds) (2008) Catálogo de las Plantas Vasculares del Cono Sur (Argentina, Sur de Brasil, Chile, Paraguay y Uruguay), vol. I: Pteridophyta, Gymnospermae y Monocotyledoneae. Missouri Botanical Garden Press, St. Louis, Missouri. 